\title{
Estimasi Jumlah Produksi CPO Kelapa Sawit Menggunakan Fuzzy Tsukamoto (Studi Kasus Pt Tapian Nadenggan)
}

\author{
F.I.Ikromina ${ }^{\# 1}$, E.I.Ujianto ${ }^{\# 2}$ \\ \# Program Magister Teknologi Informasi, Universitas Teknologi Yogyakarta \\ Jl. Siliwangi (Ringroad Utara), Jombor, Sleman D.I. Yogyakarta 55285 \\ ${ }^{1}$ fitria.ilhami.ikromina@student.uty.ac.id \\ erik.imameuty.ac.id
}

\begin{abstract}
Abstrak- PT Tapian Nadenggan memerlukan sistem estimasi jumlah produksi Crude Palm Oil (CPO) untuk menentukan standart minimum jumlah produksi dalam setiap bulannya untuk menjaga supaya target produksi terpenuhi dan meminimalisir kendala yang diakibatkan oleh kesalahan personal maupun machine. Dengan menggunakan estimasi jumlah produksi Crude Palm Oil (CPO) ini pihak perusahaan dapat diberikan kemudahan dalam mengestimasi jumlah produksi Crude Palm Oil (CPO) berdasarkan variabel banyaknya buah kelapa sawit, permintaan dan persediaan. Estimasi ini menerapkan logika fuzzy yaitu Fuzzy Tsukamoto, karena terdapat beberapa data yang bisa digunakan dalam melakukan perhitungan guna mendapatkan estimasi jumlah produksi minyak kelapa sawit. Kelebihan dari logika fuzzy memiliki konsep matematis serta memiliki toleransi terhadap data-data yang tidak tepat, mampu memodelkan fungsi-fungsi nonlinear yang sangat kompleks dan dapat bekerja sama dengan teknik-teknik kendali secara konvensional, sementara Fuzzy Tsukamoto memiliki kelebihan yaitu lebih intuitif, diterima oleh banyak pihak, lebih cocok untuk masukan yang diterima dari manusia bukan mesin. Berdasarkan basis aturan dengan menggunakan seleksi ciri hasil estimasi jumlah produksi Crude Palm Oil (CPO) dengan metode fuzzy tsukamoto bulan April 2019 dengan banyak buah kelapa sawit $36.415 .100 \mathrm{~kg}$ permintaan 7.139.620 liter, dan persediaan 2.886 .790 liter didapatkan jumlah produksi sebanyak 15.130 .992 liter. Sehingga Metode Tsukamoto efektif diterapkan dalam sistem estimasi jumlah produksi untuk membantu pihak perusahaan dalam mengestimasi jumlah produksi minyak sawit karena hasilnya mendekati dengan dataset yang ada.
\end{abstract}

Kata kunci- Buah Kelapa Sawit, Permintaan, Persediaan, Logika Fuzzy, Seleksi Ciri, Estimasi

\section{Pendahuluan}

Salah satu kegiatan yang dilakukan dalam sebuah perusahaan adalah produksi khususnya PT Tapian Nadenggan yang bergerak dalam bidang pengolahan minyak kelapa sawit. Kelapa sawit merupakan salah satu komoditas perkebunan yang mempunyai peranan penting dalam perekonomian di Indonesia. Produksi minyak kelapa sawit Indonesia terus mengalami peningkatan. Berdasarkan data statistik estimasi produksi minyak kelapa sawit Indonesia pada tahun 2017 mencapai 35.359.384 ton [1].

PT Tapian Nadenggan merupakan salah satu perusahaan yang berorientasi pada industri minyak kelapa sawit. Untuk menghasilkan produksi yang optimal diperlukan estimasi produksi yang optimal. Untuk mengestimasi produksi minyak kelapa sawit membutuhkan informasi mengenai faktor yang terlibat dalam menentukan jumlah minyak kelapa sawit yang akan diproduksi [2]. Sistem estimasi jumlah produksi minyak kelapa sawit diperlukan oleh PT Tapian Nadenggan untuk menentukan standart minimum jumlah produksi dalam setiap bulannya untuk tetap menjaga supaya target produksi terpenuhi dan meminimalkan kendala yang diakibatkan oleh kesalahan personal maupun mesin. Estimasi jumlah produksi minyak kelapa sawit dalam waktu yang tepat dan dalam jumlah yang tepat merupakan sesuatu yang diinginkan perusahaan perkebunan kelapa sawit, begitu juga bagi perusahaan PT Tapian Nadenggan. Namun dalam menentukan jumlah produksi minyak kelapa sawit di waktu yang akan datang tidak mudah. Banyaknya faktor yang terlibat dalam perhitungan menjadi kendala dalam mengambil kebijakan untuk dapat menentukan jumlah minyak kelapa sawit yang akan diproduksi. Masalah produksi banyak faktor yang mempengaruhi penentuan untuk jumlah produksi. Faktorfaktor tersebut adalah permintaan maksimum, permintaan minimum, persediaan maksimum, persediaan minimum, produksi maksimum, produksi minimum, permintaan saat ini, dan persediaan saat ini [3]. Hal ini memerlukan sebuah metode untuk mengatasai masalah tersebut yaitu optimasi produksi [4]. 
Untuk menyelesaikan masalah tersebut, pihak perusahaan hendaknya dapat membuat suatu keputusan yang tepat untuk menentukan berapa banyak jumlah produksi minyak kelapa sawit yang akan diproduksi dalam suatu perusahaan dengan memperhatikan faktor - faktor yang ada. Salah satu cara yang bisa digunakan dalam memestimasi jumlah produksi minyak kelapa sawit adalah penerapan logika fuzzy [5], karena terdapat beberapa nilai variabel yang tidak dapat diketahui pasti dalam melakukan perhitungan guna mendapatkan estimasi jumlah produksi minyak kelapa sawit [6]. Logika fuzzy digunakan karena memiliki konsep yang mudah dipahami serta dapat mengembangkan dan mengaplikasikan pengalaman pakar secara langsung tanpa harus melalui pelatihan dan didasarkan pada bahsa alami [7]. Kelebihan lain dari logika fuzzy memiliki konsep matematis serta memiliki toleransi terhadap data-data yang tidak tepat, mampu memodelkan fungsi-fungsi nonlinear yang sangat kompleks dan dapat bekerja sama dengan teknik-teknik kendali secara konvensional [8]. Ada 3 metode dalam logika fuzzy yaitu metode tsukamoto, metode mamdani dan metode sugeno. Pada penelitian ini yang digunakan diguanakan adalah metode tsukamoto karena setiap aturan direpresentasikan dengan himpunan fuzzy. Sehingga output dari setiap aturan diberikan secara tegas berdasarkan a, dan diperoleh hasil akhir dengan rata - rata terpusat. Metode ini akan menampilkan keluaan berupa nilai hasil dari perhitungan Defuzzyfikasi [9]. Fuzzy Tsukamoto memiliki kelebihan yaitu lebih intuitif, diterima oleh banyak pihak, lebih cocok untuk masukan yang diterima dari manusia bukan mesin [10], selain itu Kelebihan Model Tsukamoto terutama di banyak situasi ketidakpastian dan ketidakjelasan, metode ini sangat fleksibel dan memiliki toleransi terhadap data yang ada [11].

Beberapa hasil penelitian yang pernah dilakukan oleh peneliti sebelumnya yang memiliki bidang dan tema yang sama dengan penelitian yang akan dilakukan. Menurut [12], melakukan penelitian yang berjudul "Penerapan Metode Fuzzy Tsukamoto Untuk Memprediksi Produksi Minyak Kelapa Sawit". Penelitian ini menerapkan metode fuzzy tsukamoto dalam memprediksi produksi minyak kelapa sawit berdasarkan data kriteria pemesanan dan persediaan, yang dapat memberikan kemudahan pada perusahaan untuk mengolah data dalam memprediksi produksi minyak kelapa sawit. Penelitian ini menggunakan 9 aturan (rule) dengan hasil prediksi produksi minyak kelapa sawit pada tanggal 23 November 2017 sebesar 102.743,5 kg. Menurut [13], melakukan penelitian yang berjudul " Estimasi Jumlah Produksi Jenang di PT Menara Jenang Kudus menggunakan Metode Logika Fuzzy Tsukamoto “. Pada penelitian tersebut dibangun suatu sistem yang membantu mempermudah dalam memestimasi jumlah produksi jenang perbulannya dengan menggunakan metode Tsukamoto dengan beberapa kriteria diantaranya retur, penjualan, sisa dan produksi. Hasil dari aplikasi memberikan perkiraan estimasi hasil produksi jenang dengan tujuan untuk memudahkan perusahaan dalam memperkirakan hasil produksi jenang. Logika fuzzy yang daplikasikan untuk data di PT Menara Jenang Kudus dari bulan februari sampai september dengan hasil dari pengujian menggunakan MSE untuk jenang wijen ebesra 7.121, jenang spesial sebesar 15.940 dan jenang duren sebesar 21.168 yang menunjukkan bahwa meskipun terjadi error namun hasil prediksi masih dapat diterima. Menurut [14], melakukan penelitian yang berjudul " Aplikasi Logika Fuzzy Dalam mengoptimalkan produksi minyak kelapa sawit di PT. Waru Kaltim Plantation Menggunakan Metode Mamdani”. Penelitian ini menerapkan logika fuzzy yang mengimplementasikan fuzzy mamdani digunakan untuk memprediksi jumlah produksi minyak kelapa sawit berdasarkan data persediaan dan data permintaan. Berdasarkan hasil perhitungan yang telah dilakukan dengan variabel input permintaan 2.799.918 ton dan persediaan 1.593.21 ton pada bulan Januari 2016 mendapatkan total minyak kelapa sawit yang harus diproduksi adalah 3.085.753 ton. Untuk itu metode mamdani dapat diterapkan untuk memprediksi jumlah produksi minyak kelapa sawit di PT. Waru Kaltim Plantation (WKP), dengan keakurasian MAPE $17,225 \%$ sehingga metode fuzzy mamdani baik digunakan untuk memprediksi minyak kelapa sawit di PT WKP periode 2013 sampai 2015. Menurut [15], Melakukan penelitian yang berjudul "Penerapan Logika Fuzzy Mamdani Untuk Estimasi Hasil Produksi Ikan Air Tawar". Pada penelitian tersebut dibangun suatu sistem yang dapat menghasilkan hasil produksi ikan air tawar dengan menggunakan metode fuzzy Mamdani dengan menggunakan beberapa kriteria diantrannya siklus budidaya, debit air, jumlah bibit, jumlah pakan, dan luas kolam. Hasil dari aplikasi memberikan perkiraan hasil produksi ikan air tawar dengan tujuan untuk memudahkan para pembudidaya ikan air tawar menghasilkan hasil produksi maksimal. Hasil uji coba prediksi dengan menggunakan aplikasi diperoleh nilai produksi yang memenuhi permintaan sebesar $86,67 \%$ dari 30 data yang dipilih secara acak. Menurut [16], melakukan penelitian yang berjudul "Penerapan Metode Fuzzy Tsukamoto Untuk Memprediksi Hasil Produksi Kelapa Sawit (Studi Kasus : PT Amal Tani Perkebunan Tanjung Putri - Bahorok). Penelitian ini menggunakan 2 kriteria yaitu permintaan dan persediaan dengan menggunakan 9 aturan fuzzy, sehingga dapat menentukan berapa jumlah hasil produksi yang harus diproduksi oleh perusahaan, apakah produksinya berkurang, tetap atau bertambah. Menurut [17], melakukan penelitian yang berjudul "Application of the fuzzy Inference System Method To Predict The Number Of Weaving Fabric Production". Penelitian ini membahas penerapan logika fuzzy dalam menyelesaikan masalah produksi menggunakan Metode Tsukamoto dan metode Sugeno. Masalah yang dipecahkan adalah bagaimana menentukan produksi kain tenun bila menggunakan tiga variabel sebagai input data, yaitu: stok, permintaan dan inventaris produksi biaya. Menurut metode Tsukamoto pada bulan Maret 2017 menggunakan aturan Weka diperoleh 343 kain tenun dalam meter, sementara menggunakan metode sugeno diperoleh 371 kain tenun dalam meter. Sedangkan menurut metode 
Tsukamoto di Maret 2017 menggunakan aturan monoton diperoleh 313 kain tenun dalam meter, kemudian menggunakan metode Sugeno memperoleh 321 kain tenun dalam meter, sedangkan menurut data produksi perusahaan pada Maret 2017 menghasilkan 340 kain tenun dalam meter, kemudian dari analisis perbandingan langsung dengan data asli di perusahaan dapat disimpulkan bahwa metode yang paling dekat dengan nilai kebenaran adalah produksi yang diperoleh oleh memproses data menggunakan metode Tsukamoto menggunakan aturan Weka.

Dari semua uraian di atas bertujuan dengan adanya sistem estimasi jumlah produksi ini pihak perusahaan dapat melakukan estimasi lebih cepat. Sehingga diharapkan dapat memberikan kemudahan bagi pihak perusahaan untuk memestimasi jumlah produksi minyak kelapa sawit berdasarkan variabel input berupa data buah kelapa sawit, permintaan dan persediaan sedangkan variabel output berupa jumlah produksi.

\section{Metode PENELITIAN}

\section{A. Cara Studi Literatur}

Metode ini digunakan penulis untuk mendapatkan bekal teori acuan untuk melakukan penelitian. Teori pustaka terkait yang menjadi referensi penulis adalah logika fuzzy. Studi literatur ini akan menjadi bahan acuan dan dasar teori sebagai penunjang penelitian dan penulisan skripsi.

B. Pengamatan Di Lapangan

Metode ini digunakan untuk mengetahui pengamatan susunan pekerjaan dilapangan.

\section{Metode Pengembangan Sistem}

Langkah pengembangan sistem sebanyak 8 tahapan, dimana penjelasannya sebagai berikut:

1) Pengumpulan Data: Pengumpulan data dilakukan di PT Tapian Nadenggan. Pengumpulan data dilakukan dengan cara wawancara secara tidak langsung kepada pihak Staff Produksi di PT Tapian Nadenggan. Data yang diperoleh data buah kelapa sawit (kg), permintaan (liter), persediaan (Liter), Produksi (Liter) dari bulan Januari 2013 sampai bulan Maret 2018 dengan 63 data yang diperoleh.

2) Analisis data set: Analisis data set berdasarkan data di PT Tapian Nadenggan yang akan digunakan untuk proses fuzzy inference system menggunakan variabel input berupa data buah kelapa sawit, permintaan, persediaan dan variabel output berupa jumlah produksi sebagai dataset untuk diproses dengan data uji yang akan diestimasi. Data buah kelapa sawit, permintaan, persediaan dan jumlah produksi akan dijadikan nilai batasan dengan mencari nilai himpunan dari masingmasing variabel. Nilai himpunan untuk masing-masing variabel diantarannya buah kelapa sawit banyak (43.500.000 $\mathrm{Kg})$, buah kelapa sawit sedang $(30.036 .150 \mathrm{Kg})$, buah kelapa sawit sedikit $(16.572 .300 \mathrm{Kg})$, permintaan naik (18.920.000 Liter), permintaan sedang (11.036.666,5 Liter), permintaan turun (3.153.333 Liter), persediaan banyak (5.000.000 Liter), persediaan sedang (2.916.666,5 Liter), persediaaan sedikit (833.000 Liter), produksi bertambah (19.800.000 Liter), produksi sedang (12.900.000 Liter) dan produksi berkurang (6.000.000 Liter).

3) Seleksi Ciri: Langkah awal untuk membuat aturan pada weka yaitu mengisikan semua data sampel di Microsoft Exel. Berdasarkan kasus data yang dimasukkan yaitu data buah kelapa sawit, permintaan, persediaan dan produksi dari bulan Januari 2013 sampai bulan Maret 2018 sebanyak 63 data sampel. Setelah itu simpan file dengan format csv. Tampilan kalsifikasi seperti pada gambar 1.Tahapan penelitian yang dilakukan seperti ditunjukkan pada gambar 1 berikut ini:

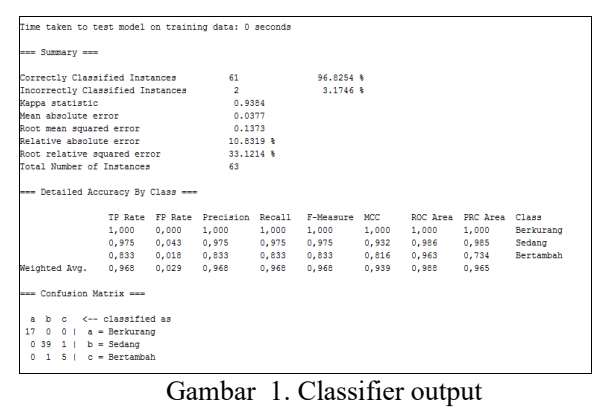

Dari Gambar 1 diketahui bahwa dari 63 sampel data yang benar dalam klasifikasi sebanyak 61 data dan klasifikasi yang salah sebanyak 2 data. Tingkat keakurasinnya yaitu $96.8254 \%$.

4) Aturan Seleksi Ciri: Proses membuat aturan seleksi ciri dengan melihat pohon keputusan didapat dengan klik kanan pada result list tree kemudian pilih visualize tree, maka akan muncul tampilan seperti pada gambar 2 .

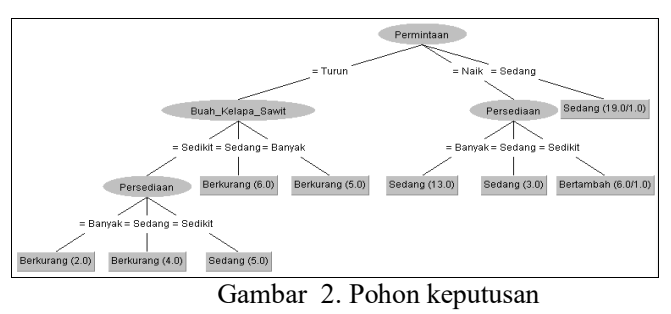

Dari gambar 2 dapat disimpulkan bahwa aturan seleksi ciri yang terbentuk sebagai berikut :

[R1] IF Buah kelapa sawit SEDIKIT and Permintaan TURUN and Persediaan BANYAK then Produksi BERKURANG

[R2] IF Buah kelapa sawit SEDIKIT and Permintaan TURUN and Persediaan SEDANG then Produksi BERKURANG

[R3] IF Buah kelapa sawit SEDIKIT and Permintaan TURUN and Persediaan SEDIKIT then Produksi SEDANG

[R4] IF Buah kelapa sawit SEDANG and Permintaan TURUN then Produksi BERKURANG

[R5] IF Buah kelapa sawit BANYAK and Permintaan TURUN then PRODUKSI then Produksi BERKURANG 
[R6] IF Buah Permintaan NAIK and Persediaan BANYAK then Produksi SEDANG

[R7] IF Buah Permintaan NAIK and Persediaan SEDANG then Produksi SEDANG

[R8] IF Buah Permintaan NAIK and Persediaan SEDIKIT then Produksi SEDANG

[R9] IF Permintaan SEDANG then Produksi SEDANG

5) Desain Fungsi Keanggotaan: Desain fungsi keanggotaan berdasarkan variable variabel yang sudah ditentukan beserta semesta pembicaraan, variabel itu adalah buah kelapa sawit, permintaan, persediaan setelah itu mencari derajat keanggotaan suatu himpunan fuzzy, berdasarkan nilai linguistik yang akan digunakan. Linguistik yang digunakan dapat dilihat pada tabel 1 .

TABEL I

LINGUITIK YANG DIGUNAKAN

\begin{tabular}{|l|l|}
\hline \multicolumn{1}{|c|}{ Variabel } & \multicolumn{1}{c|}{ Nama Linguistik } \\
\hline Buah kelapa sawit & Sedikit, sedang, banyak \\
\hline Permintaan & Turun, sedang, naik \\
\hline Persediaan & Sedikit, sedang, banyak \\
\hline produksi & $\begin{array}{l}\text { Berkurang, sedang, } \\
\text { bertambah }\end{array}$ \\
\hline
\end{tabular}

Adapun fungsi keanggotaan untuk memestimasi jumlah produksi minyak kelapa sawit dapat dilihat fungsi keanggotaan buah kelapa sawit pada Gambar 3.

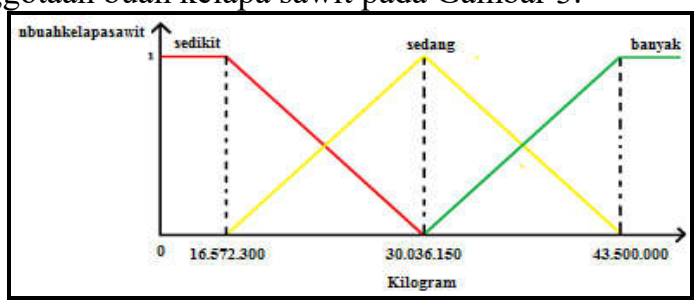

Gambar 3. Fungsi keanggotaan buah kelapa sawit

Fungsi keanggotaan variabel buah kelapa sawit

$\mu_{\text {Fielapasawit-sedihit [a] }}$

$\left\{\begin{array}{c}\frac{1}{30036150-a} \\ 0\end{array}\right.$

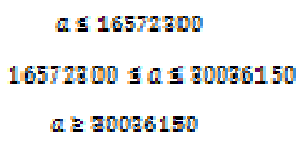

$\mu_{k \text { silavasawit-sedang [a] }}$

$\left\{\begin{array}{cc}0 & 43500000 \leq a \leq 16572300 \\ \frac{a-16572300}{30036150-16572300} & 16572300 \leq a \leq 30036150 \\ \frac{43500000-a}{43500000-30036150} & 30036150 \leq a \leq 43500000 \\ 1 & a=30036150\end{array}\right.$

Hklauasawit-Banvak [a]

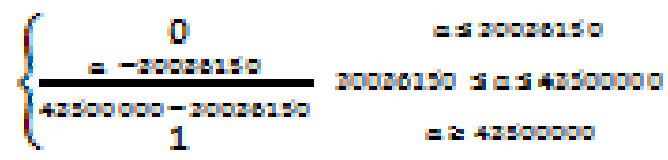

Adapun fungsi keanggotaan untuk memestimasi jumlah produksi minyak kelapa sawit dapat dilihat fungsi keanggotaan permintaan pada Gambar 4.

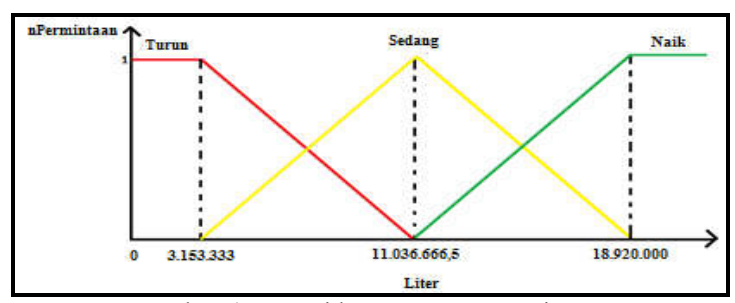

Gambar 4. Fungsi keanggotaan permintaan

Fungsi keanggotaan variabel Permintaan

Hpermintaan-turun [a]

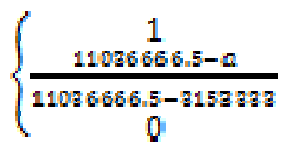

451322:2

715777 g a 110760605

a 211036665

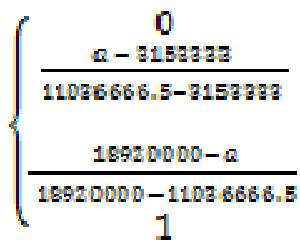

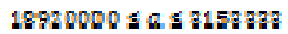

315202: sas 1102666 s

110ะ6อง $5 \mathrm{~s}$ a 516720000

$a=70096150$

Mpermintaan-ianyak [a]

$\left\{\frac{0-110^{0} 66655}{10920000-110356655}\right.$

a $\leq 11036665$

$110366655 \leq \leq 10920000$

a. $>1890000$

Adapun fungsi keanggotaan untuk memestimasi jumlah produksi minyak kelapa sawit dapat dilihat fungsi keanggotaan persediaan pada Gambar 5.

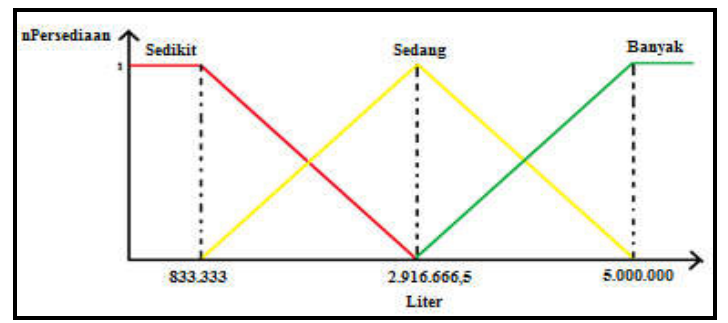

Gambar 5. Fungsi keanggotaan persediaan 
Fungsi keanggotaan variabel Persediaan

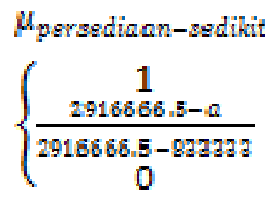

a.sezaza

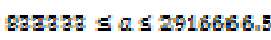

$0 \pm 29266665$

$\mu_{\text {persedian-sedang }[a "}$

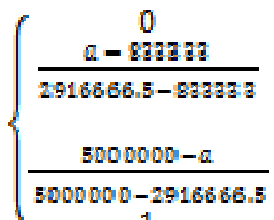

$50000004 a \pm \operatorname{sanga}$

garag 4 a 429166665

$29166665 \pm$ a s 5000000

$a=2002 \$ 150$

$\mu_{\text {persediaan-banyak [a] }}$

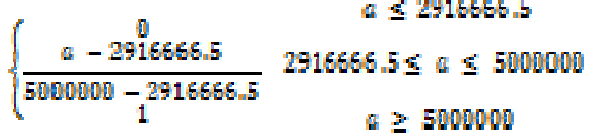

Adapun fungsi keanggotaan untuk memestimasi jumlah produksi minyak kelapa sawit dapat dilihat fungsi keanggotaan jumlah produksi pada Gambar 6.

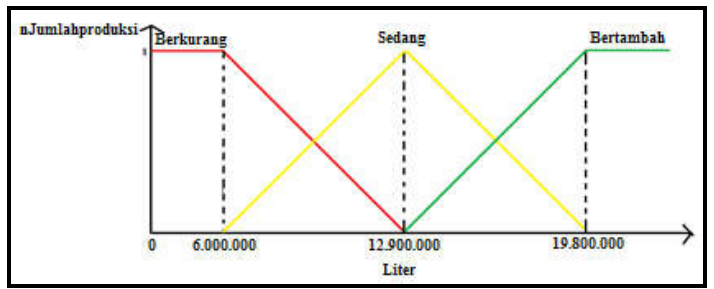

Gambar 6. Fungsi keanggotaan jumlah produksi

Fungsi keanggotaan variabel Produksi

$A_{\text {produhsi-Derhurang }[a]}$
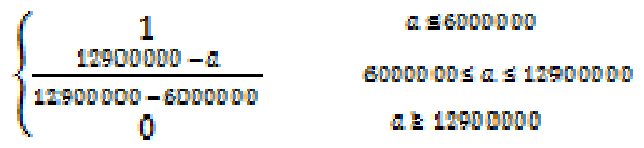

HproduFisi-sedang [a]
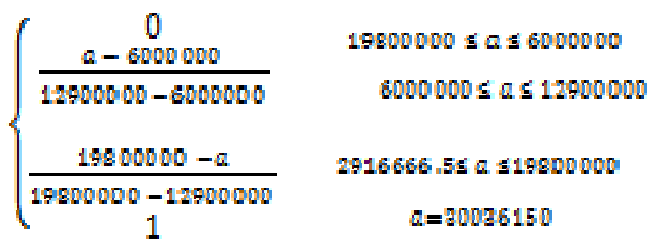

Aprodufusi-banyati [a]

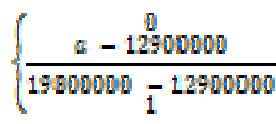

$$
\text { a } \leq 12900000
$$

$12900000 \leq a \leq 19000000$

a $\geq 19000000$
6) Inferensi: Pada inferensi menggunakan metode Tsukamoto untuk melakukan proses perhitungan sampai dengan diperoleh hasil estimasi jumlah produksi minyak kelapa sawit. Adapun langkah-langkah Fuzzy Inference System menentukan himpunan fuzzy, mencari nilai keanggotaan dan di gambarkan dengan kurva, menentukan himpunan operasi AND, dan terakhir yaitu penalaran monoton.

7) Hasil Estimasi Jumlah Produksi Minyak Kelapa Sawit Dengan Rule Seleksi Ciri: Pada tahap ini adalah tahap terakhir yaitu diperolehnya hasil estimasi jumlah produksi minyak kelapa sawit dengan rule seleksi ciri menggunakan metode Tsukamoto.

\section{HASIL DAN PEMBAHASAN}

Semua Untuk kasus diatas terdapat 4 variabel, yaitu 3 variabel input dan 1 variabel output. Variabel input terdiri dari buah kelapa sawit dengan 3 nilai linguistik banyak, sedang, sedikit, sedangkan permintaan dengan 3 nilai linguistik naik, sedang, turun, dan persediaan dengan 3 nilai linguistik banyak, sedang, sedikit. Penyelesain dengan aturan monoton dan Aturan seleksi ciri.

\section{A. Step 1}

Menentukan variabel yang berhubungan dengan kasus. Pada kasus ini terdpaat 4 variabel yang akan dimodelkan, yaitu :

1) Buah kelapa sawit: Mencari Nilai Keanggotaan variabel buah kelapa sawit

$$
\begin{aligned}
& \mu_{\text {Kelapasawit-Sedikit [a6415100] }=0}
\end{aligned}
$$

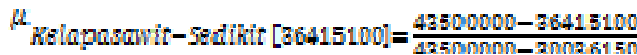

$$
\begin{aligned}
& \begin{array}{l}
=\frac{7084900}{13463850} \\
=0,5262165
\end{array} \\
& =\frac{6079950}{18469850}
\end{aligned}
$$

$$
=0,4737835
$$

2) Permintaan: Mencari Nilai Keanggotaan variabel permintaan

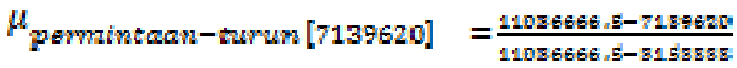

$$
\begin{aligned}
& =\frac{38970465}{78890335}
\end{aligned}
$$

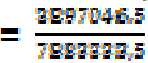

$$
\begin{aligned}
& =0.49499999
\end{aligned}
$$

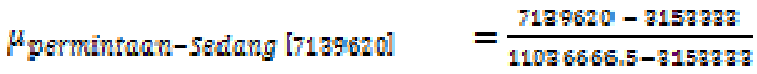

$$
\begin{aligned}
& =\frac{3986287}{7883393.5} \\
& =0,50566007
\end{aligned}
$$


Apaminanan-nak [71ag6ai] =0

3) Persediaan: Mencari Nilai Keanggotaan variabel persediaan

$\mu_{\text {pergediaan-Sedikit }[2886790]}=\frac{2916666,5-2886790}{29166665-999895}$

$$
=\frac{29876,5}{20060335}
$$$$
=0,01434072
$$

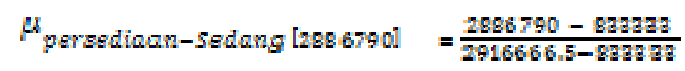

$$
=\frac{2053457}{2083339.5}
$$

$=0.98565928$

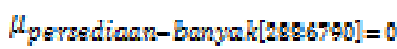

B. Step 2

Proses inferensi (pembentukan rule). Dengan fungsi min untuk mencari nilai z pada setiap aturannya.

[R1] IF buah kelapa sawit SEDIKIT and Permintaan TURUN and Persediaan BANYAK then Produksi BERKURANG

$a_{\text {-prdikat1 }}=\mu_{\text {buahkelapasawit-sedikit }} \cap \mu_{\text {perwintaan-rumun }} \cap \mu_{\text {persediaan-banyak }}$ min( $\mu_{\text {halapasuit-satikit }[36415100] \mathrm{n}}$

$$
\begin{aligned}
& \mu_{\text {semintana-turun }}[7139620] \cap \\
& \mu_{\text {persediaan }- \text { banyak }}[2886790] \\
& =\min (0 ; 0,49433993 ; 0) \\
& =0
\end{aligned}
$$

Hproduksi-berkurang [a]

$$
\left\{\begin{array}{cc}
A_{\text {produkgi-berkurang }[a]} & a \leq 6000000 \\
\frac{1}{12900000-a} & 6000000 \leq a \leq 12900000 \\
0 & a \geq 12900000
\end{array}\right.
$$

$\frac{12900000-z 1}{6900000}=0 \rightarrow Z 1=12900000-0=12900000$

[R2] IF buah kelapa sawit SEDIKIT and Permintaan TURUN and Persediaan SEDANG then Produksi BERKURANG


$=$ $\min \left(\mu_{\text {halapaswit-sathit }}[36415100] \cap\right.$

Hemintann-tww [7139620]ก Hersediann-sadand [2886790] $=\min (0,0,49439993,0,98565928)$

$$
=0
$$

Hproduksi-berkwnang [a]

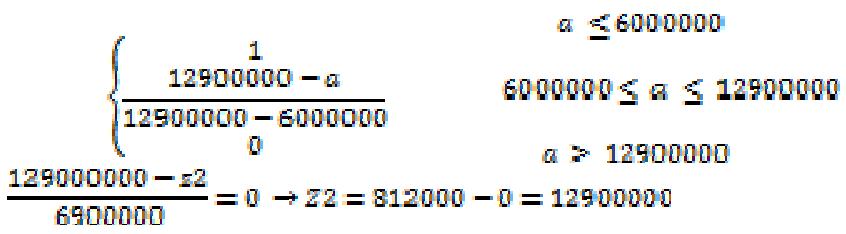

[R3] IF buah kelapa sawit SEDIKIT and Permintaan TURUN and Persediaan SEDIKIT then Produksi SEDANG

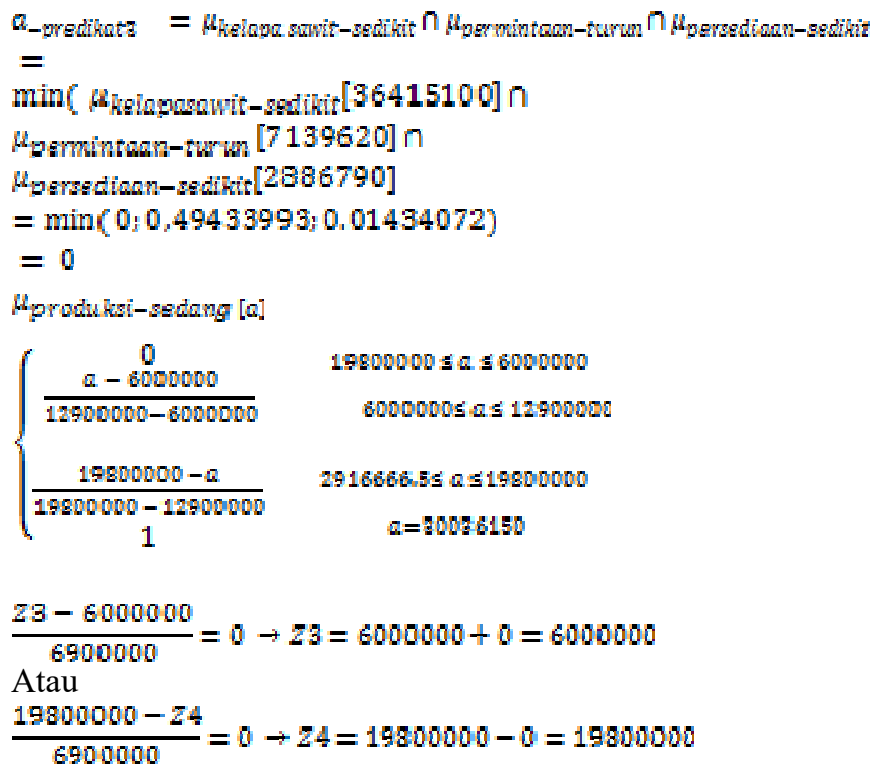

[R4] IF buah kelapa sawit SEDANG and Permintaan TURUN then Produksi BERKURANG

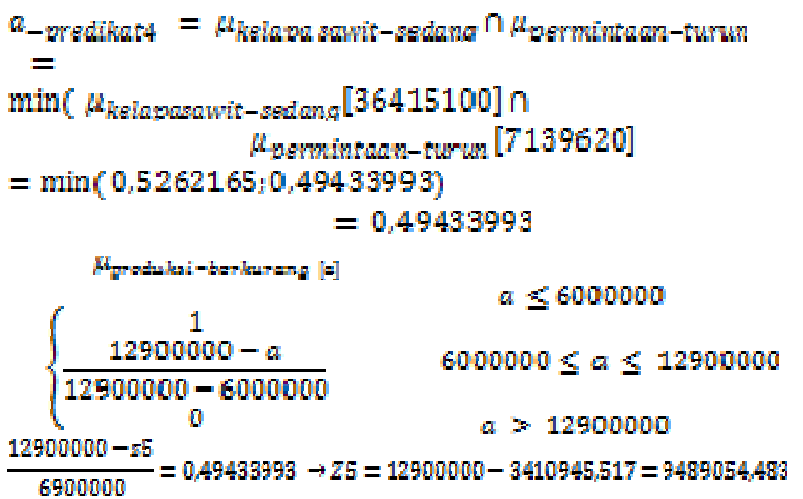

[R5] IF buah kelapa sawit BANYAK and Permintaan TURUN then Produksi BERKURANG

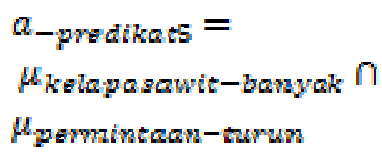




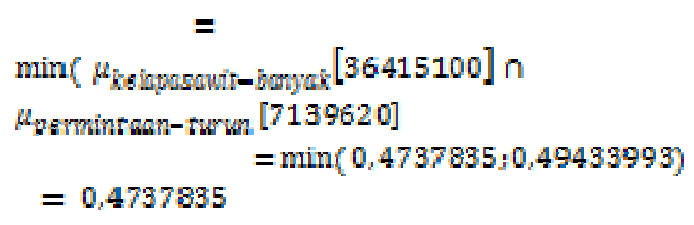

Hproduksi-berkurang [a]

$\left\{\frac{12900000-a}{12900000-6000000}\right.$

$a \leq 6000000$

$\frac{12900000-z 6}{6900000}=0,4737835 \rightarrow Z 6=12900000-3269106,15=9630693,65$

[R6] IF Permintaan NAIK and Persediaan BANYAK then Produksi SEDANG

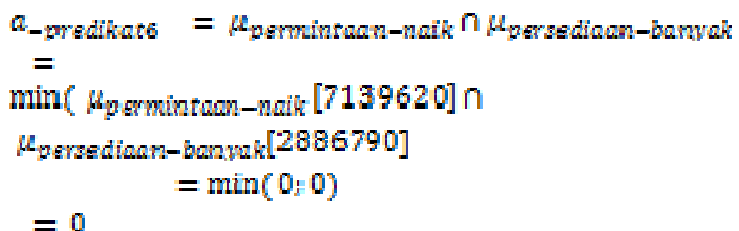

$=0$

Hproduhsi-sedang [a] $\left\{\begin{array}{c}\frac{a-6000000}{12900000-6000000} \\ \frac{19900000-a}{19500000-12900000} \\ 1\end{array}\right.$

19500000 s a $\leq 6000000$ E000000ธ a 12700000

2916665 as19000000 $\Delta=30026150$

$\frac{Z 7-6000000}{6900000}=0 \rightarrow Z 7=6000000+0=6000000$

Atau

$\frac{19800000-Z 8}{6900000}=0 \rightarrow Z 8=19800000-0=19800000$

[R7] IF Permintaan NAIK and Persediaan SEDANG then Produksi SEDANG

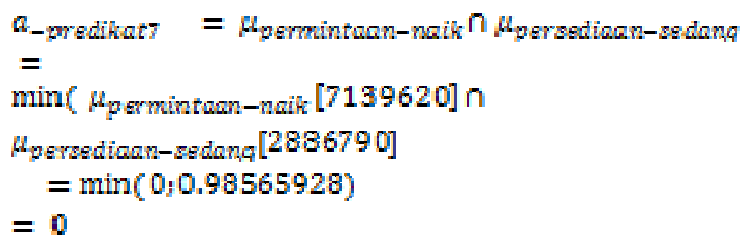

Aproduhsi-dedang [a]

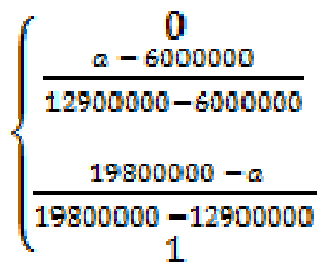

$$
\begin{gathered}
19800000 \leq a \leq 6000000 \\
6000000 \leq a \leq 12900000 \\
2916666.5 \leq a \leq 19800000 \\
a=30036150
\end{gathered}
$$

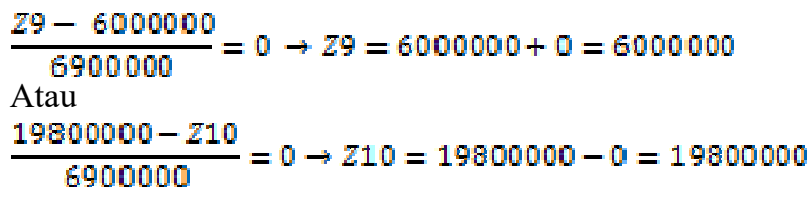

[R8] IF Permintaan NAIK and Persediaan SEDIKIT then Produksi SEDANG

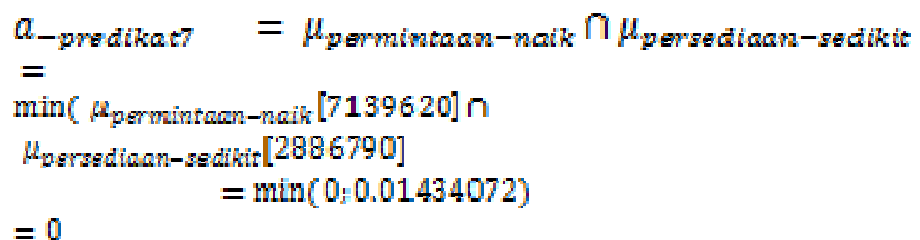

Aproduksi-banyak[a]

$$
\left\{\begin{array}{cc}
a-12900000 & 12900000 \leq a \leq 19800000 \\
\frac{19000000-12900000}{1} & a \geq 19800000
\end{array}\right.
$$

$\frac{z 11-12900000}{6900000}=0 \rightarrow Z 11=12900000+0=1290000$

[R9] IF Permintaan SEDANG then Produksi SEDANG

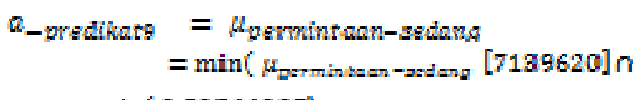

$=\min (0,50566007)$

$=0,50566007$

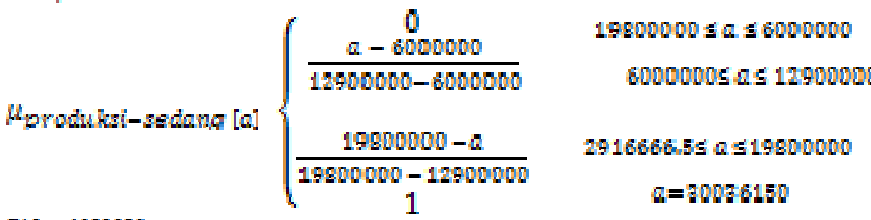

$\frac{Z 12-6000000}{6900000}=0,60566007+Z 12=6000000+3489054,489=9489054,488$

Atau

$\frac{19800000-Z 13}{6900009}=0,50566007-Z 13=19800000-3489054,483=16310945,517$

C. Step 3

Hasil akhir diperoleh dengan mengguanakan rata-rata terbobot (deffuziikasi)

$\mathbf{Z}:(\mathrm{a} 1 * \mathrm{z} 1+\mathrm{a} 2 * \mathrm{z} 2+\mathrm{a} 3 * \mathrm{z} 3+\mathrm{a} 3 * \mathrm{z} 4+\mathrm{a} 4 * \mathrm{z} 5 * \mathrm{a} 5 * \mathrm{z} 6$ $+\mathrm{a} 6 * \mathrm{z} 7+\mathrm{a} 6 * \mathrm{z} 8+\mathrm{a} 7 * \mathrm{z} 9+\mathrm{a} 7 * \mathrm{z} 10+\mathrm{a} 8 * \mathrm{z} 11+\mathrm{a} 9 *$ $\mathrm{z} 12+\mathrm{a} 9 * \mathrm{z} 13$ )

$(\mathrm{a} 1+\mathrm{a} 2+\mathrm{a} 3+\mathrm{a} 4+\mathrm{a} 5+\mathrm{a} 6+\mathrm{a} 7+\mathrm{a} 8+\mathrm{a} 9)$

$\mathbf{Z}:(0 * 12900000+0 * 12900000+0 * 6000000+0$ * $19800000+0,49433993 * 9489054,483+0,4737835 *$ $9630893,85+0 * 6000000+0 * 19800000+0 * 6000000+0$ $* 19800000+0 * 12900000+0,50566007 * 9489054,483+$ $0,50566007 * 16310945,517)$

$(0+0+0+0,49433993+0,4737835+0+0+0+0,50566007)$

$\mathbf{Z}:(0+0+0+0+4690818,529+4562958,596+0+0+0+$ $0+0+4798235,954+8247793,852)$
1.4737835
$\mathrm{Z}: \frac{22299806.931}{1,4737835}$
$\mathrm{Z}: \mathbf{1 5 . 1 3 0 . 9 9 2}$ 


\section{Perhitungan menggunakan aplikasi}

Memasukkan data buah kelapa sawit, permintaan dan persediaan yang akan dilakukan estimasi jumlah produksinya. Berikut tampilan memasukkan data terlihat pada gambar 7 .

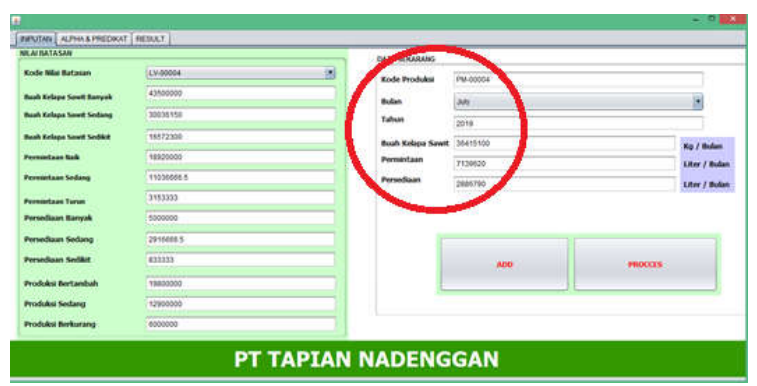

Gambar 7. Memasukkan data

Perhitungan dengan Rule Seleksi Ciri terlihat pada gambar 8.

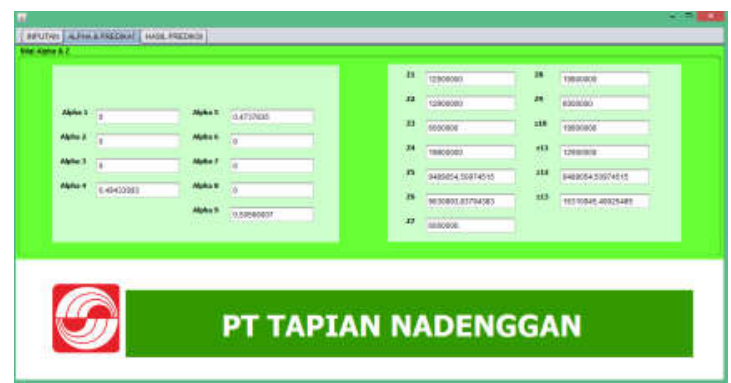

Gambar 8. Perhitungan rule seleksi ciri

Hasil Estimasi jumlah produksi dengan rule seleksi ciri terlihat pada gambar 9 .

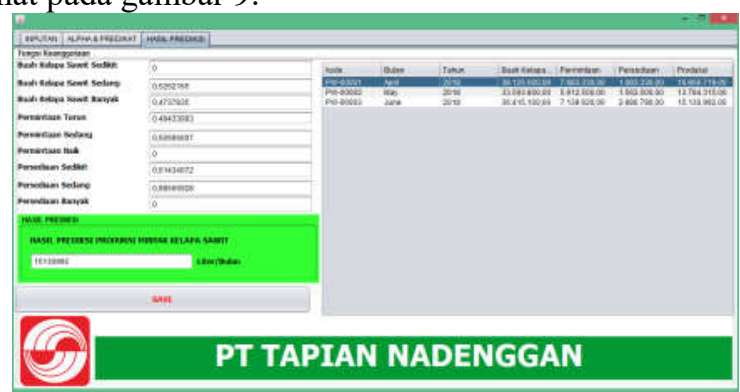

Gambar 9. Hasil estimasi jumlah produksi CPO kelapa sawit

Dapat disimpulkan bahwa hasil estimasi jumlah produksi Crude Palm Oil (CPO) menggunakan fuzzy tsukamoto dengan aturan yaitu seleksi ciri dengan buah kelapa sawit 36.415.100 $\mathrm{kg}$, permintaan 7.139.620 liter dan persediaan 2.886.790 liter menghasilkan estimasi jumlah produksi Crude Palm Oil (CPO) sebanyak 15.052.830 liter.

\section{KESIMPULAN}

Berdasarkan pembahasan mengenai penerapan metode Fuzzy Tsukamoto dalam memestimasi jumlah produksi minyak kelapa sawit berdasarkan variabel input berupa data buah kelapa sawit, permintaan dan persediaan, maka dapat disimpulkan:

a. Metode Tsukamoto efektif diterapkan dalam sistem estimasi jumlah produksi untuk membantu pihak perusahaan dalam memestimasi jumlah produksi minyak sawit berdasarkan variabel input buah kelapa sawit, permintaan dan persediaan serta variabel output jumlah produksi.

b. Aturan yang digunakan dalam penelitian ini menggunakan aturan seleksi ciri.

c. Berdasarkan basis aturan dengan menggunakan seleksi ciri hasil estimasi jumlah produksi minyak kelapa sawit dengan metode Fuzzy Tsukamoto sebagai Bulan Juni 2018 sebanyak 15.130.992 Liter

d. Hasil estimasi jumlah produksi minyak kelapa sawit yang dihasilkan dapat disimpulkan bahwa dengan aturan seleksi ciri hasilnya mendekati dengan dataset yang ada. Dengan klasifikasi sampel data benar yang didapatkan di aplikasi Weka 96, 8254\%, sehingga aturan seleksi ciri yang didapatkan dari Weka dapat digunakan dalam penelitian ini..

\section{REFERENSI}

[1] Direktorat Jenderal Perkebunan, Statistik Perkebunan Indonesia 2015 2017 Kelapa Sawit., (2016).

[2] Fitra, T.Y., (2014), Aplikasi Sistem Fuzzy Untuk Prediksi Harga Crude Palm Oil (CPO), Skripsi Universitas Negeri Yogyakarta.

[3] Salikin, F., (2011), Aplikasi Logika Fuzzy dalam Optimasi Produksi Barang Menggunakan Metode Sugeno, Universitas Negeri Yogyakarta, Yogyakarta.

[4] Abdurrahman, G., (2011), Penerapan Metode Tsukamoto (Logika Fuzzy) dalam Sistem Pendukung Keputusan untuk Menentukan Jumlah Produksi Barang Berdasarkan Data Persediaan dan Jumlah permintaan, Skripsi, Universitas Negeri Yogyakarta, Yogyakarta.

[5] Rhmann, W and Saxena, V., (2017), Fuzzy Expert System Based Test Cases Prioritization from UML State Machine Diagram using Risk Information, International Journal of Mathematical Sciences and Computing(IJMSC), Vol.3, No.1, pp.17-27.

[6] Solikin (2011), Aplikasi Logika Fuzzy Dalam Optimalisasi Produksi Barang Menggunakan Metode Mamdani Dan Metode Sugeno, Skripsi Matematika Universitas Negeri Yogyakarta.

[7] Sutojo,T, Mulyanto, E and Suhartono, V., (2011), Kecerdasan buatan, Ygyakarta:Andi.

[8] Kusumadewi, S., (2010), Aplikasi Logika Fuzzy untuk pendukung Keputusan, Yogyakarta: Graha Ilmu.

[9] Shidiq, M.Z., (2014), Sistem Pendukung Keputusan Penetuan Jumlah Produksi Barang Dengan Metode Fuzzy Tsukamoto, Skripsi Tenik Informatika, Universitas Dian Nurwantoro, Semarang.

[10] Thamrin,F., (2012), Studi Inferensi Fuzzyy Tsukamoto Untuk Penetuan Faktor Pembebanan Trafo PLN, Tesis Sistem Informasi, Universitas Diponegoro, Semarang.

[11] Singh, G., Kunai, P, and D. Goyal., (2014), A review fuzzy logic and its application, International Journal of Engineering and Technical Research, pp. 61-66. 
[12] Aminah, Saputra, K and Niska, D.Y., (2018), Penerapan Metode Fuzzy Tsukamoto Untuk Memprediksi Produksi Minyak Kelapa Sawit, Prosiding SNITIK.

[13] Azmi, T. U., Haryanto, H., dan Sutojo, T., (2018), Estimasi Jumlah Produksi Jenang di PT Menara Jenang Kudus Menggunakan Metode Logika Fuzzy Tsukamoto, Jurnal, Teknik Informatika, Universitas Dian Nurwantoro, Semarang.

[14] Wardani, A.R., (2017), Aplikasi Logika Fuzzy Dalam Mengoptimalkan Produksi Minyak Kelapa Sawit Di PT. Waru Kaltim Plantation Menggunakan Metode Mamdani, Jurnal Informastika Mulawarman, Vo 12 No 2.

[15] Rahmadziba, F., (2016), Penerapan Logika Fuzzy Mamdani Untuk Estimasi Hasil Produksi Ikan Air Tawar, Universitas Islam Negeri Sunan Kalijaga.

[16] Juliansyah, A., (2015), Penerapan Metode Fuzzy Tsukamoto Untuk Memprediksi Hasi Produksi Kelapa Sawit (Studi Kasus : PT Amal Tani Perkebunan Tanjung Putri-Bahorok), Vol.9 No 3.

[17] Tundo, Sela, E I., (2018), Application Of The Fuzzy Inference System Method To Predict The Number Of Weaving Fabric Production, Internaional Journal On Informatics For Development, Vol 7, No 1. 